\title{
Electoral Competition for Outsiders, Conservative Power, and Restrictive Social Policy in Mexico
}

\section{Citation}

Garay, Candelaria. 2016. "Electoral Competition for Outsiders, Conservative Power, and Restrictive Social Policy in Mexico." In Social Policy Expansion in Latin America, 222-60. Cambridge: Cambridge University Press.

\section{Published Version}

https://doi.org/10.1017/9781316585405.006

\section{Permanent link}

http://nrs.harvard.edu/urn-3:HUL.InstRepos:37108551

\section{Terms of Use}

This article was downloaded from Harvard University's DASH repository, and is made available under the terms and conditions applicable to Other Posted Material, as set forth at http:// nrs.harvard.edu/urn-3:HUL.InstRepos:dash.current.terms-of-use\#LAA

\section{Share Your Story}

The Harvard community has made this article openly available.

Please share how this access benefits you. Submit a story.

Accessibility 


\title{
Social Policy Expansion in Latin America
}

\author{
CANDELARIA GARAY \\ Kennedy School of Government, Harvard University
}

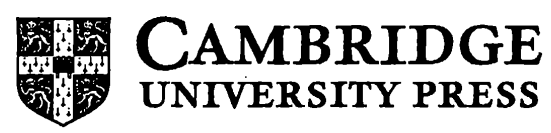




\section{CAMBRIDGE UNIVERSITY PRESS}

One Liberty Plaza, New York, NY I0006, USA

Cambridge University Press is part of the University of Cambridge.

It furthers the University's mission by disseminating knowledge in the pursuit of education, learning, and research at the highest international levels of excellence.

www.cambridge.org

Information on this title: www.cambridge.org/978 3 I 6606407

I0.1017/978I3I6585405

(C) Candelaria Garay 2016

This publication is in copyright. Subject to statutory exception and to the provisions of relevant collective licensing agreements, no reproduction of any part may take place without the written permission of Cambridge University Press.

First published 2016

Printed in the United States of America by Sheridan Books, Inc.

A catalogue record for this publication is available from the British Library.

ISBN 978-I-I07-I 5222-9 Hardback

ISBN 978-I-3 I 6-60640-7 Paperback

Cambridge University Press has no responsibility for the persistence or accuracy of URLs for external or third-party Internet Web sites referred to in this publication and does not guarantee that any content on such Web sites is, or will remain, accurate or appropriate. 


\section{Electoral Competition for Outsiders, Conservative Power, and Restrictive Social Policy in Mexico}

\section{I INTRODUCTION}

In the final months of Mexico's 2000 presidential campaign, Vicente Fox of the National Action Party (PAN), a conservative party that would soon govern the country after seventy-one years of uninterrupted rule by the Institutional Revolutionary Party (PRI), visited impoverished rural towns that had historically been the bulwark of the PRI. In explaining why he was pursuing an unusual strategy for a PAN candidate - and one that also implied a shift away from his earlier campaign - Fox stated:

We have to break the PRI's wall in rural areas, we have to attract followers from other parties because there are virtually no more undecided voters to compete for ... [the goal is] to break the tie we have maintained with the PRI over the past three months and that is now beginning to cede. In the poll I received today, we are a little ahead, 40.7 percent vs. 40.5 percent of Labastida [the PRI's candidate]. We are in these towns because we are pursuing small gains in specific areas of the population, such as women and the peasants... [It is this new stage of the campaign] that will allow us to break the tie and leave Labastida behind. ${ }^{\mathrm{r}}$

The emergence of intense electoral competition for outsiders after decades of PRI rule coincides with a period of large-scale social policy expansion in Mexico that constitutes an important effort to "include outsiders" and to temper the social policy divide between insiders and outsiders. After the inauguration of a smaller program of income transfers by PRI president Ernesto Zedillo in 1997, the expansion of large-scale health care services, income support, and pension benefits for outsiders began under the Fox administration (2000-6). By 20I0, at least 36 percent of

\footnotetext{
I Quoted in "Busca Fox el voto rural en Huasteca potosina," Reforma March 25, 2000, p. 8.
} 
TABLE 6.I Social Policy Expansion and the Restrictive

Model in Mexico, ca. 20 Io

\begin{tabular}{|c|c|c|c|c|}
\hline $\begin{array}{l}\text { Policy } \\
\text { Area }\end{array}$ & $\begin{array}{l}\text { Scope of } \\
\text { Coverage }\end{array}$ & $\begin{array}{l}\text { Benefit } \\
\text { Level }\end{array}$ & $\begin{array}{l}\text { Participation in } \\
\text { Implementation }\end{array}$ & $\begin{array}{l}\text { Dates of } \\
\text { Expansion }\end{array}$ \\
\hline $\begin{array}{l}\text { Income } \\
\text { Support }\end{array}$ & \begin{tabular}{l}
\multicolumn{1}{c}{ Low } \\
36\% of \\
school-age \\
outsider \\
children
\end{tabular} & \begin{tabular}{l}
\multicolumn{1}{c}{ Moderate } \\
Less than $20 \%$ \\
of the poverty \\
line for a \\
family with \\
two children
\end{tabular} & None & $200 I-3$ \\
\hline $\begin{array}{l}\text { Health } \\
\text { Care }\end{array}$ & $\begin{array}{l}\text { Low } \\
\text { Free access for } \\
\text { poor outsiders; } \\
\text { about } 40 \% \\
\text { of outsiders } \\
\text { enrolled }\end{array}$ & $\begin{array}{l}\quad \text { Moderate } \\
\text { Exclusion of } \\
\text { some services } \\
\text { and treatments }\end{array}$ & None & $\begin{array}{l}2003 \\
\text { (adoption } \\
\text { and gradual } \\
\text { implementation) }\end{array}$ \\
\hline Pensions & $\begin{array}{l}\text { Low } \\
48 \% \text { of } \\
\text { outsiders } \\
\text { aged } 65+\end{array}$ & $\begin{array}{l}\quad \text { Low } \\
33 \% \text { of the } \\
\text { minimum } \\
\text { pension for } \\
\text { insiders }\end{array}$ & None & $\begin{array}{l}\text { Oportunidades- } \\
\text { seniors: } 2006 \\
\text { 70 y Más: } 2006-7 \\
\text { (adoption); } 2007 \\
\text { (implementation) }\end{array}$ \\
\hline
\end{tabular}

Notes: Dates of Expansion refers to adoption and launching of implementation. Pensions: characterization refers to 70 y Más, which replaced Oportunidades-seniors.

Sources and measures: See Appendix I.

children received income transfers; $4 \mathrm{I}$ percent accessed subsidized health insurance, and about 48 percent of outsiders sixty-five and older had noncontributory pensions (Table 6.I).

At first glance, the expansion of social policy in Mexico is surprising given the political affiliation of the Fox government and the absence of large export revenues in the 2000s, as Mexico did not experience a commodity boom in this period in contrast to several South American countries. In this setting, why were nondiscretionary benefits launched for outsiders under the PAN administrations of Fox and Felipe Calderón (2006-I2)? Why did the PAN, a conservative party with a core constituency in the economic elite, not launch small or even discretionary benefits, as the PRI had done in the past?

This chapter shows that the expansion of nondiscretionary, restrictive social policy began as a result of intense electoral competition for outsiders 
within a democratic regime. In this competitive electoral context, incumbents embarked on social policy expansion to consolidate the support of outsiders and to offset the appeals of credible competitors seeking to cultivate their support. Without reelection in place, the ultimate goal was the continuation of the incumbent party in office. Due to the absence of mobilization from below triggering and/or shaping the process of social policy design, these benefits were negotiated among political parties in Congress - especially the center-right PAN and the populist PRI, both of which had conservative social policy preferences - and resulted in more modest, nonparticipatory policy initiatives. Mexico therefore provides a good example of social policy expansion and social policy design under strong conservative power, a topic that remains understudied in the context of the regional turn to the left in the 2000 (see Levitsky and Roberts 201 I; Weyland et al. 2010). ${ }^{2}$

In the next section of this chapter, I trace the evolution of electoral competition beginning in the I990s, as Mexico democratized. I show how electoral competition for outsiders compelled incumbents to launch social policy expansion and why restrictive policies were created. First, I analyze the surge of electoral competition under Ernesto Zedillo (1994-2000) and the initial policy responses of the PRI president as democratization and electoral competition for outsiders deepened. When democratization intensified and support for opposition parties grew in the late I990s, the Zedillo administration extended a still relatively small cash-transfer program which was nondiscretionary in an effort to avoid allegations of clientelism voiced by the invigorated opposition from PAN and the PRD. Next, in section four, I analyze social policy expansion after the defeat of the PRI in 2000. Having assumed power in a democracy with high levels of electoral competition for outsiders, Fox launched large-scale social policy expansion to solidify outsiders' support. Electoral competition for outsiders was intense at the end of Fox's tenure, with the ascendance of the left-wing Party of the Democratic Revolution (PRD) candidate Andrés Manuel López Obrador (AMLO), who campaigned on large-scale social policy expansion. Electoral pressure led Fox to embark on further social policy innovations to prevent the defeat of the PAN in upcoming elections, which were extremely close and in which outsiders supported both the PRD and PAN candidates in comparable shares. Given that some aspects of these policy innovations were either implemented or modified under the Felipe Calderón administration (2006-I2), I refer to Calderón's government in the analysis of specific policy areas in section four. Finally, I assess the role of other explanations

\footnotetext{
${ }^{2}$ Forthcoming work by Estevez, Díaz Cayeros, and Magaloni on Mexico is an exception.
} 
for social policy expansion, focusing on structural economic change, partisan politics, and the diffusion of new ideas of social protection.

\subsection{EVOLUTION OF ELECTORAL COMPETITION FOR OUTSIDERS AND SOCIAL MOBILIZATION}

Electoral competition for outsiders emerged as part of the process of democratization that resulted in the victory of PAN in the 2000 election and in the emergence of a three-party system with high levels of competition for national office. After decades of uncontested victories and legislative supermajorities for the PRI, voter de-alignment from the PRI began in the late I980s and intensified in the I990s, encouraging opposition parties to appeal to these voters and seek office. ${ }^{3}$ When the vote share for the PRI declined, and the party lost its supermajority in the lower chamber, the Carlos Salinas administration (1988-94) negotiated with the PAN a series of electoral reforms in I99I and 1993 in exchange for support for its economic reform agenda, which required constitutional changes. These reforms established the Electoral Tribunal and the Federal Electoral Institute (IFE) to oversee elections (Magaloni 2006: 90) and created a more auspicious environment for the growth of opposition parties. Although these reforms helped make national-level elections clean, the presidential election of 1994 was still not fair due to large incumbent advantages (Levitsky and Way 2010: 158 ).

Further institutional changes were carried out as competition increased in the mid-r990s. Comprehensive negotiations among parties launched by Zedillo materialized in reforms that guaranteed the independence of the IFE and introduced fundamental changes to electoral institutions in 1994 and 1996 - including rules on campaign finance (Levitsky and Way 20IO: I 59; Lujambio 200I; Magaloni 2006: 94). Analysts argue that these changes reduced the advantage the PRI had over opposition parties (Camp 2004: 28), allowing for opposition victories in municipal elections and the celebration of clean and fair elections at the national level in subsequent years (Lujambio 200I: 87). These opposition victories helped persuade voters that peaceful alternation was possible (Camp 2004: 27; Magaloni 2006: 94), facilitating the growth of both PAN and PRD in the 1997 legislative elections, which ended the PRI's majority in the lower chamber, and the PAN's victory in the 2000 presidential election (see Figure 6.I).

3 See Bruhn (I997 chap. 3); Klesner (2005). 


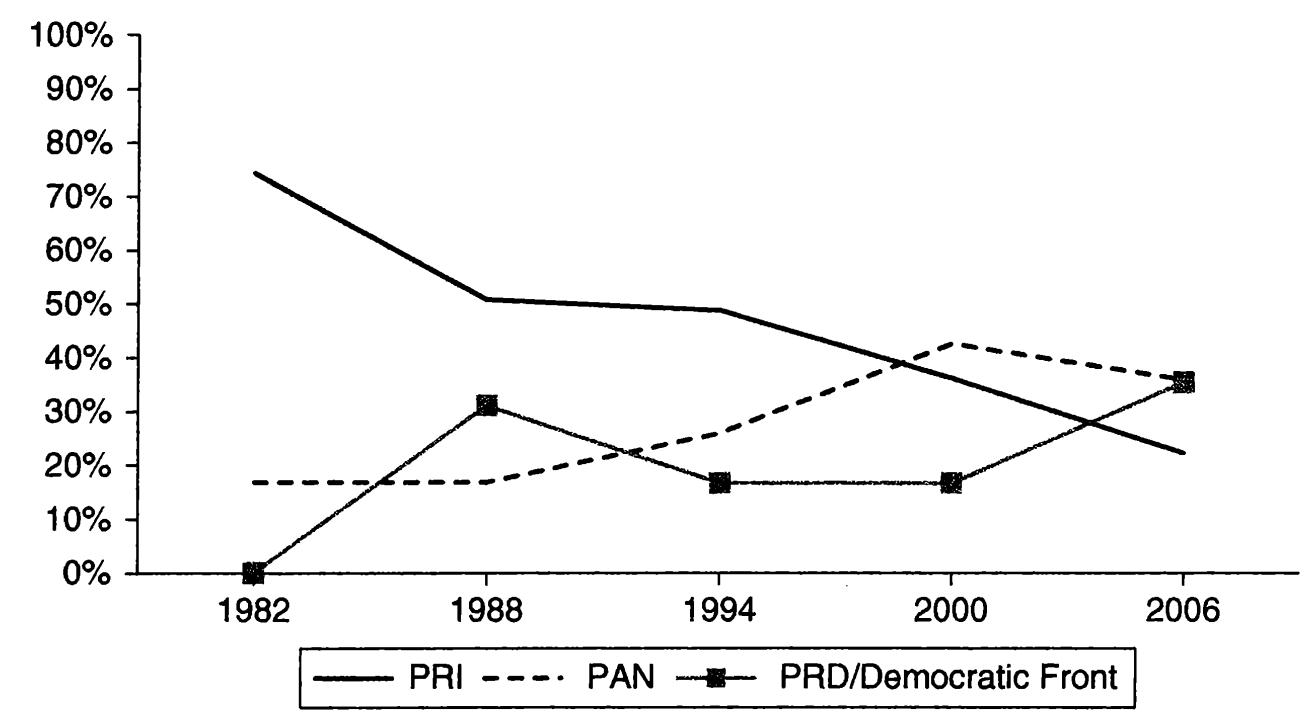

FIGURE 6.I Vote share in presidential elections, Mexico I982-2006. Source: IFE.

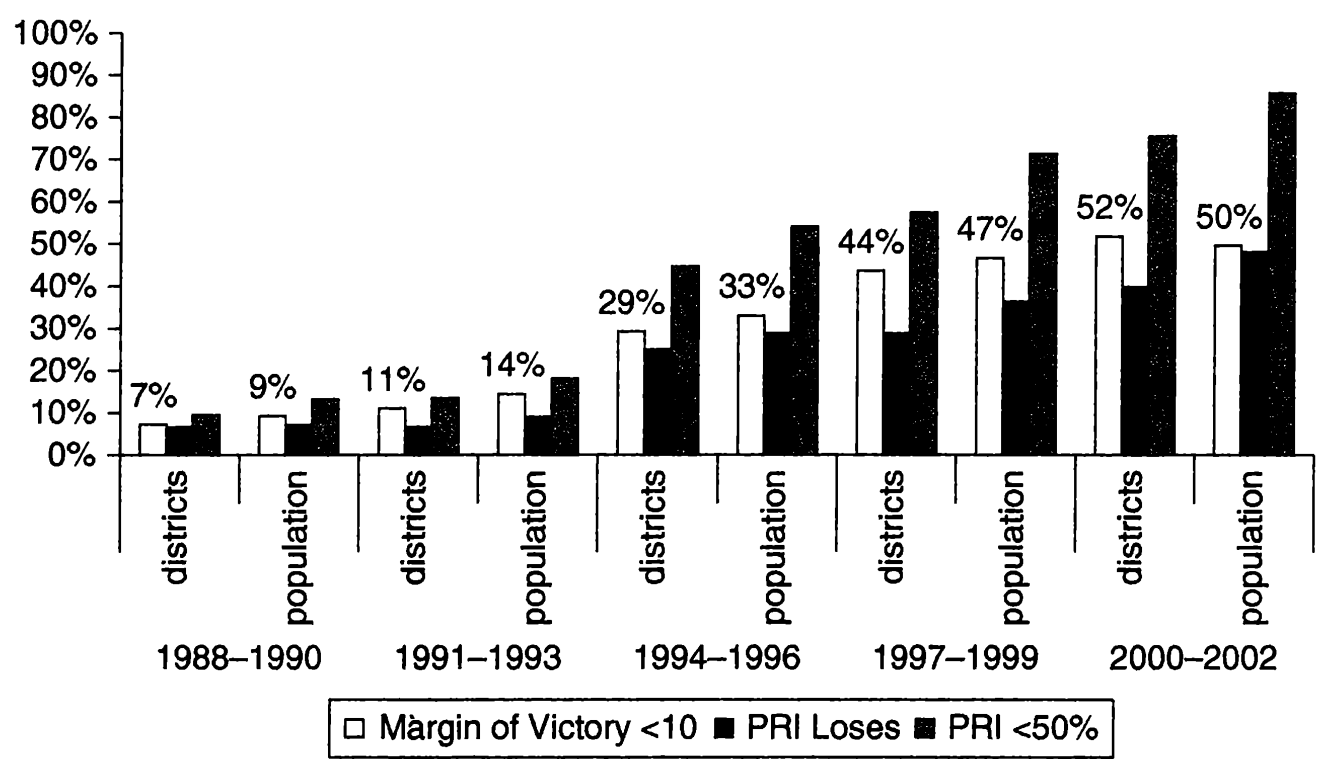

FIGURE 6.2 Electoral competition in municipal elections, Mexico, I9882002 ( $\%$ outsider districts and population in outsider districts with electoral competition).

Source: Elaborated with data from INEGI and CIDAC.

Electoral competition for outsider voters also grew in the r990s, particularly surrounding the 2000 presidential elections. Figure 6.2 provides a snapshot of these changing electoral dynamics. Given the absence of individual-level survey data on outsiders' electoral choices before the 2000 s or ecological data on presidential elections at the district level, I work with results from municipal elections, for which systematic data 
since the late 1980 ox exists. As with the other cases in this book, I focus on "outsider" municipalities - those in which outsiders comprised at least 55 percent of the total population. ${ }^{4}$ These districts totaled I,908 of the 2,443 municipalities in Mexico, and comprised around 50 percent of the country's population and 65 percent of the outsiders as of 2000 . Several of these municipalities were typically considered the bulwark of the PRI; in the heyday of the dominant party system, the PRI obtained victories with close to Ioo percent of the votes in some of these districts. In the I988-90 electoral cycle, ${ }^{5}$ for example, the PRI obtained less than 50 percent of the vote share in only 9.5 percent of these districts.

Electoral competition in outsider municipalities began to grow in the 1994-6 cycle, when opposition parties expanded initially in urban areas, and was even higher at the end of the decade. I use three indicators to measure these changes in electoral dynamics: the percent of outsider municipalities and percent of the outsider population in outsider municipalities in which: (a) the margin of victory is less than ten points; (b) the PRI loses (any party other than the PRI is victorious); and (c) the PRI obtains less than 50 percent of the vote share. Given the PRI's smashing victories in previous years, these measures map the erosion of its electoral support and the expansion of the opposition.

In Figure 6.2 we see that close competition and opposition victories intensified at the end of the decade. Whereas in 1988-90, elections were close in around 7 percent of districts, by 1997-9, this figure had jumped to 44 percent. At the same time, the share of municipalities in which the PRI received less than 50 percent of the vote jumped from about 45 percent to 74.5 percent between 1994 and 2002 , compared to 9.5 percent and 13.3 percent in 1988 and I99I, respectively.

Ecological electoral data of presidential elections in outsider municipalities are available for 2000 and 2006 . As noted, I measure electoral competition looking at the share of outsider municipalities in which the challenger wins and/or the margin of difference between the first and second party in the presidential election is less than ten points. If electoral competition is present in at least 50 percent of outsider municipalities or the outsider municipalities experiencing electoral competition hold at least 50 percent of the outsider population in these municipalities, I score that presidential election as having electoral competition for outsider voters. In Figure 6.3, we see that in both elections there is competition

${ }_{4}$ This is based on the 2000 census.

5 Municipal elections are carried out every three years. Because municipalities do not use the same electoral calendar, I grouped the years in which each municipality holds its election into three-year electoral cycles. 


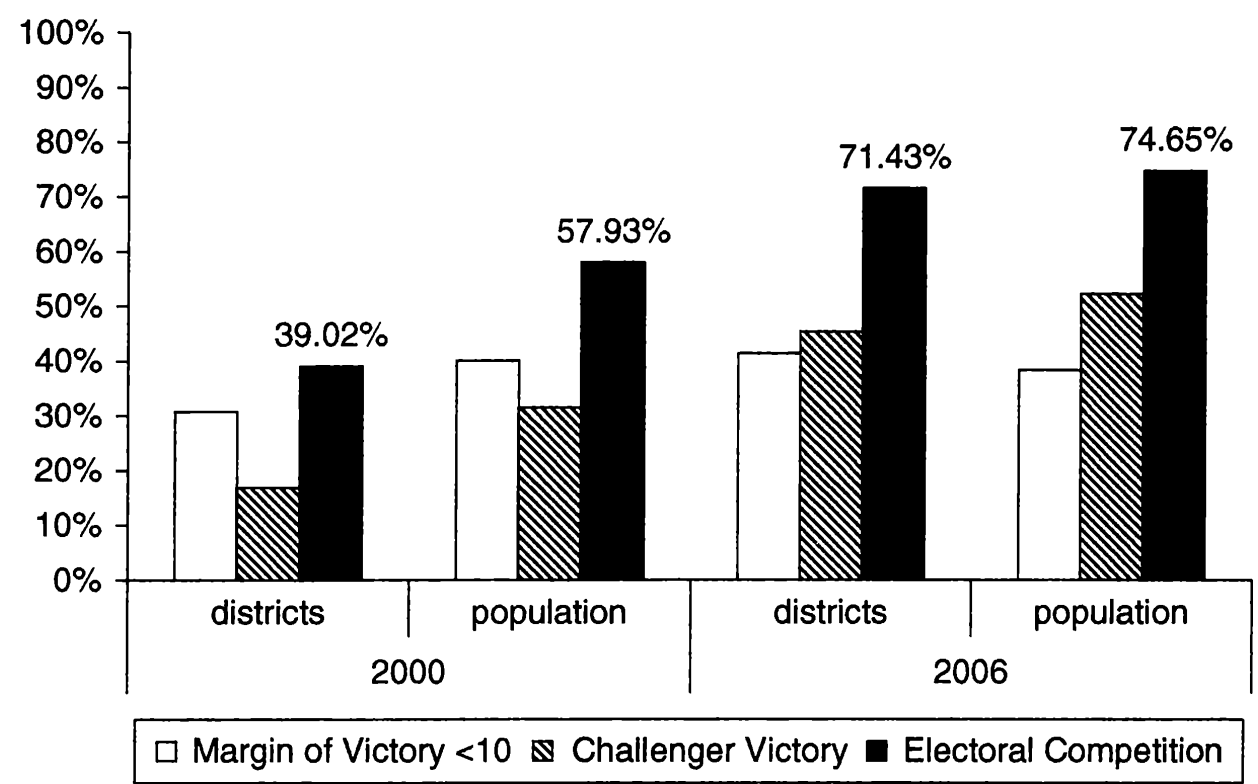

FIGURE 6.3 Electoral competition for outsiders in presidential elections, Mexico, 2000-2006 (\% outsider districts and population in outsider districts with electoral competition).

Source: Calculated with socioeconomic data from INEGI and electoral data from CIDAC.

for outsiders. This competition concerns mainly the PRI (incumbent) and PAN (challenger) in 2000 and the PAN (incumbent) and PRD (challenger) in 2006.

A final systematic assessment of electoral competition for outsider voters consists of analyzing voting patterns with individual-level data, which are available for the 2000 and 2006 presidential elections. These data allow for an estimation of electoral competition for the vote of outsiders at a national scale. With postelection surveys carried out by CIDE-CSES, I classify voters into outsiders and insiders and estimate their vote choices (see Appendix 3 for measures). Two indicators are used to measure the presence of electoral competition for outsider voters with these data: whether the vote margin between the two most voted parties favored by outsider voters is less than ten percentage points and/or whether the challenger wins the most votes from outsiders.

Figure 6.4 shows that competition for these voters was high between 2000 and 2006. In 2000, the PRI faced a credible competitor in the PAN, which according to these data won the most votes among outsiders. By 2006, competition was further heightened. The PAN again received the most votes, but faced a rising credible challenge from the PRD, which 


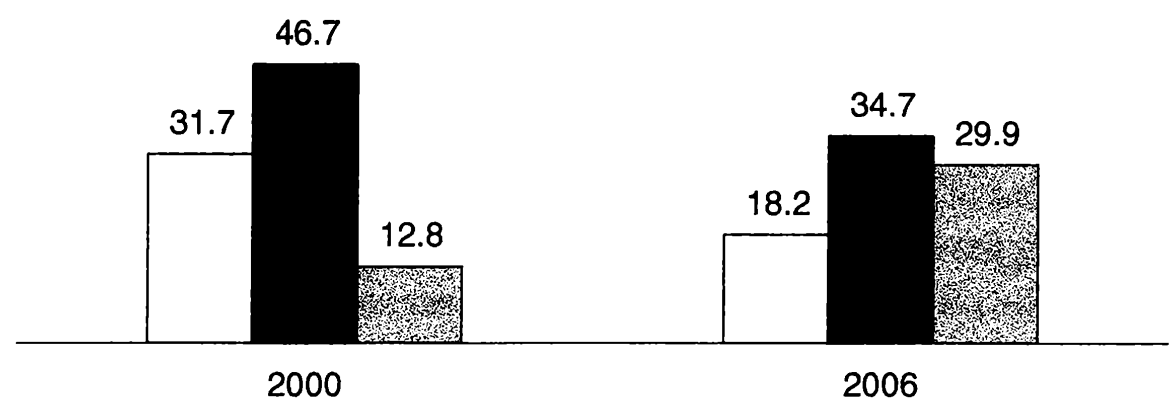

\section{$\square$ PRI $\square$ PAN 圈 PRD}

FIGURE 6.4 Reported vote of outsiders in presidential elections, Mexico, 2000-2006 (percent vote share).

Source: Elaborated with post-election surveys done by CIDE-CSES in July of 2000 and July and August of 2006 (elections took place each year in the month of July).

doubled its vote share among outsiders and narrowed PAN's vote margin, according to these data.

\section{Social Mobilization}

Social mobilization - understood as the sustained demand for social policy by a coalition of social movements and labor unions - did not take shape in Mexico in the I990s and 2000s. Mexico did witness, however, the formation of an indigenous movement whose main component was the Zapatista Liberation Army (EZL) that emerged in Chiapas in the r990s and staged an armed insurrection in 1994. The Zapatistas demanded better living conditions for indigenous peoples and made claims centered on the recognition of their rights as indigenous peoples alongside demands for democratization (see Trejo 20I 2; Yashar 2005: 26).

Despite the Zapatistas' political relevance, their movement does not fit the characterization of what is here defined as a social movement coalition (SMC), which leads national incumbents to respond with largescale social policy provisions. The Zapatistas did not forge linkages with other political and social actors to form a national movement advancing a social policy agenda. The Zapatistas remained quite isolated from national-level actors, as well as from other rural movements. The Chiapas conflict remained geographically bounded, and over time became increasingly identified with cultural claims for indigenous autonomy, rather than with its initial economic demands (see Trejo 2004). 
The government sought to prevent the movement from expanding beyond Chiapas and responded to the Zapatistas with development programs directed specifically to that state and often administered by the movement itself. ${ }^{6}$ The wide-reaching mobilization demanding social benefits that triggered expansion in Argentina and Brazil was not present in Mexico at the national level or coordinated across rural areas throughout the period.

\subsection{THE DEMOCRATIC TRANSITION AND SOCIAL POLICY RESPONSES}

Electoral competition grew dramatically during the Zedillo administration. After winning the presidency comfortably, the PRI lost every major subnational election in 1995. In 1997, the PRI lost its majority in the lower chamber, inaugurating the first divided government in Mexico's post-Revolutionary history (see Lujambio 200I). Facing electoral decline, and also considering the possibility that subsequent elections would involve growing levels of competition for outsiders (local-level elections in 1994 and 1995 showed inroads by the opposition into areas in which outsiders represented the majority of the population, as shown in Figure 6.2), Zedillo initiated social policy reforms. He dismantled PRONASOL, which was perceived and criticized as highly discretionary, by transferring its infrastructure and social investment funding to states and municipalities, and initiated PROGRESA, a social program that granted nondiscretionary, individual social transfers. PROGRESA constituted the basis on which expansion under democracy would be built, but owing to its limited scope it does not constitute a large-scale expansion as here defined. The goal of this section is to lay out the drivers of social policy change as competition heightened.

\section{The Ernesto Zedillo Administration (1994-2000)}

A deep political and economic crisis contributed to the discrediting of the PRI and the rapid growth of electoral competition after Zedillo assumed

\footnotetext{
${ }^{6}$ Several interviews with PRD, PRI, and PAN politicians and technocrats involved in social programs such as Oportunidades, PRONASOL, and PROGRESA denied the insurgency's impact on the state's decision to launch PROGRESA in 1997. The benefit was extended to Chiapas in 1998. Several interviews also noted the importance of resources being directed to Chiapas specifically to prevent the conflict from expanding or escalating. On the Zapatistas and the state, see Eisenstadt (2009).
} 
office. ${ }^{7}$ A succession of events in the last year of the Salinas administration unleashed the crisis. In January 1994, the peasant-led Zapatista uprising in Chiapas challenged the PRI government. Among a battery of demands, insurgents expressed opposition to the North American Free Trade Agreement (NAFTA) that Salinas had signed, initiating a rebellion the day the agreement went into effect. The Chiapas conflict revealed deleterious living conditions among indigenous populations and was accompanied by episodes of violence.

Political turmoil incentivized capital flight, showing the vulnerability of Mexico's financial policy, which was based on an overvalued exchange rate and high interest rates (Kessler 1998). The uprising was further followed by the assassination of PRI presidential candidate Luis Donaldo Colosio at a campaign rally in March r994. Political instability produced further capital flight, which Salinas managed to check by spending reserves to control the exchange rate (Kessler I998: 58) and by appointing Zedillo, a technocrat and Colosio's campaign manager, as presidential candidate. In a bleak scenario, Zedillo won the election, largely benefiting from Salinas' popularity, who at that time still enjoyed high approval ratings of about 63 percent, and from the enormous advantages and access to state resources that the PRI still enjoyed over its competitors. ${ }^{8}$ However, more political assassinations, ${ }^{9}$ disclosure of corruption in Salinas' clique, and a new round of armed conflict in Chiapas induced further capital flight before Zedillo's inauguration. After assuming office in December 1994, Zedillo launched a devaluation that triggered the peso crisis and produced a dramatic economic downturn, causing a 6 percent drop in the GDP and rising unemployment in 1995 (see Kessler 1998; Wise 2003).

The discrediting of Salinas and the PRI, along with the dramatic collapse of the economy, undermined electoral support for the party. In the months following Zedillo's inauguration, the PRI lost key urban areas to the opposition (Lujambio 200I: 85-6). As noted in Figure 6.2, competition grew between 1994 and 1999 in outsider municipalities as well. Moreover if we break up the $1994-6$ electoral cycle, we see that whereas in 1994 the PRI lost in 23.I percent of local elections, in 1996 this figure jumped to 34.4 percent (author's estimate). At the state level, the

7 On democratization, see Levitsky and Way (2010); Magaloni (2006); Wise (2003).

${ }^{8}$ Approval ratings from CIDE 2008 in Murillo (2009: 206).

9 These events include the murder of José Francisco Ruíz-Massieu, Salinas' former brotherin-law and secretary general of the PRI and charges against Raúl Salinas, the president's brother, for alleged involvement in the crime. 
opposition won fourteen of the thirty-one gubernatorial races between I994 and 2000 (Magaloni 2006: 54).

The growth of the opposition put pressure on Zedillo to initiate social policy reforms. A target of criticism was PRONASOL, the social program strongly identified with the Salinas administration. ${ }^{\text {Io }}$ PRONASOL lacked clear rules for benefit distribution, and was perceived as a fundamental pillar of Salinas' strategy to perpetuate the PRI in power. Empowered by the president's declining backing, legislators and subnational authorities of the opposition advocated the decentralization of social expenditures to both reduce the manipulation of resources by the national government and increase the power of local governments (interviews, Boltvinik, Vélez). ${ }^{\text {II }}$ They further promoted the passage of a Social Development Law as well as other mechanisms that would limit discretion in social policy allocations from the national government. ${ }^{12}$

Pressure to decentralize social expenditures also came from the president's own party. Just as the opposition was winning subnational elections, subnational PRI politicians began to gain power vis-à-vis an enervated president. Like the opposition, subnational PRI authorities hoped to administer more funds themselves and limit discretion in the allocation of resources on the part of the federal government in a political environment of unprecedented levels of competition (interviews, Marván, Vélez, Boltvinik).

In response, the Zedillo administration initiated two changes regarding social policy: (a) the gradual establishment of the Program of Education, Health, and Nutrition (PROGRESA), a nondiscretionary cash-transfer program that would be the backbone of his antipoverty strategy, and (b) the decentralization of PRONASOL's funding, which culminated in the dismantling of the program.

In 1994, Zedillo assigned two technocratic teams to design an alternative social program to PRONASOL. One team was led by José Gómez de León, head of the National Population Council (CONAPO). The other team, in charge of designing the financial structure for the new benefit, was led by Santiago Levy and was based within the Secretariat of Finance. Both teams operated independently from secretary of social development Carlos Rojas, the architect of PRONASOL.

ro See Chapter 3.

II See Cámara de Diputados (1996; 1997).

${ }_{12}$ See La Jornada, July 8, I995. The I997 and I998 congressional debates of the annual budget in the lower chamber are indicative of these concerns. 
Contributions from both teams of experts resulted in the design of a nondiscretionary scheme that provided grants to low-income families with children conditional on school attendance and health checkups. The new program had nonparticipatory implementation. Wary about the potential identification of the program with the political targeting of PRONASOL under the Salinas administration, key officials claimed that the new benefit had to be "the antithesis" of PRONASOL, excluding all community participation that could open the door to manipulation of benefits (interviews, Székely).

PROGRESA, then called the Nutrition, Health, and Education Program (PASE), was piloted in 1995 and 1996 , which provided evidence of its technocratic credentials, the program's future impact, and the way it would reach beneficiaries. The program was launched after the 1997 midterm elections. Although the PRI majority in Congress approved funding for PROGRESA in the 1997 annual budget, the Zedillo administration waited to launch the program until after the competitive midterm election in order to prevent legislators and public opinion from associating the new scheme with electoral calculations ${ }^{\mathrm{I} 3}$ and clientelism. Zedillo's advisors feared public opinion would consider PROGRESA "Zedillo's PRONASOL." " 4 Allegations of discretion in social programs were voiced by the opposition in Congress within the debates over the I997 budget, whose approval was not endorsed by the PAN or the PRD (Cámara de Diputados, December II, I996).

PROGRESA started out with 300,000 beneficiaries in 1997 and was expanded over the next years to reach close to 2.47 million households and 2.48 million children before the 2000 presidential election. In I998, when the PRI lacked a majority in the lower chamber - which is in charge of approving the budget - the PAN supported the expansion of PROGRESA (Cámara de Diputados, December I3, I997). The PRD opposed it. Legislator Demetrio Sodi sustained that funding for PROGRESA had increased " $550 \%$ " and criticized what he said was a "totally clientelistic" program (Cámara de Diputados, December I3, 1997). Fears and allegations of benefit manipulation still affected its implementation.

Although PROGRESA represents an innovation in Mexico's social policy for outsiders, its design borrowed from PRONASOL's Children in Solidarity scheme, which had been established to combat child labor

I3 See "Pide Rojas apoyar programas sociales," Reforma, August 8, I997.

${ }^{14}$ See Levy (2006: 108 fn 35). 
in rural areas (interviews, Hernández, Rojas). According to Rojas, "PROGRESA [was] the continuation of Children in Solidarity," which provided a small grant in exchange for school attendance and medical checkups for children selected by Solidarity Councils (see Chapter 3; interview, Rojas).

PROGRESA differed from Children in Solidarity in two fundamental ways. A distinctive feature of Children in Solidarity was the presence of social participation, which was avoided in PROGRESA out of concerns about discretion in the program's allocation. As Rojas noted in an interview:

[Children in Solidarity] was an individual benefit but it nonetheless had an important community-involvement component. By contrast, in PROGRESA what you see is the criterion of ... killing social participation ... of individualizing everything. (interview, Rojas)

At the same time, PROGRESA's beneficiary selection process involved technocratic teams who based decisions on clear eligibility criteria, whereas in the case of Children in Solidarity, community councils determined access. In the words of a former director of PROGRESA:

"Mexico had a package [of school grants] that was called Children in Solidarity... There were thousands of communities that received forty school grants each. Who received those grants within those communities? Who knows. The idea was to provide a more or less fixed number of grants to each community and then leave the community ... to decide how to distribute those grants the best possible way. This was a festival of criteria. (interview, Hernández)

With respect to PRONASOL, the administration's goal was to dismantle its structure. By 1996, Zedillo had begun to increase PRONASOL's direct transfers to municipalities. When the PRI lost the majority in the lower chamber in 1997, a more plural legislature pushed for further decentralization. Funding for infrastructure investments was decentralized according to a revenue-sharing formula defined by Congress, which made allocations more transparent. Other smaller schemes included within PRONASOL, such as Enterprises in Solidarity, were either kept within the Secretariat of Social Development (SEDESOL) or transferred to other national-level agencies. Opposition parties in Congress vigorously promoted decentralization. The PAN voted favorably for the annual budget in 1997 to a large extent owing to these concessions. ${ }^{15}$

is See Cámara de Diputados, December I3, 1997. On decentralization, see Sour et al. (2004). 
The new rule-based automatic allocation of former PRONASOL funding to subnational units eliminated national-level discretion and negotiations over these funds. ${ }^{16}$ However, states and municipalities in charge of spending those resources enjoyed ample room for discretion. ${ }^{17}$ The key point, however, is that the national executive, pressured to reduce discretion, decentralized PRONASOL - and other national programs - through clear criteria and implemented PROGRESA, which was highly targeted and technocratic.

When PROGRESA began implementation, opposition politicians worried about how benefits were actually distributed, especially whether beneficiaries were deceived by patronage networks that required them to work for local authorities in order to maintain their benefits or that scared them away from voting for opposition parties on the grounds that they would lose their benefits if the opposition won. As seen in other countries analyzed in this book, such problems emerged in the programs' early years, when new benefits were inaugurated against a background of entrenched clientelistic relations. Although these practices were not pervasive with respect to cash transfers, and the distribution of benefits was largely nondiscretionary, national officials still acknowledged their existence in the 2000 s and made significant efforts to prevent them (interview, Gómez-Hermosillo, director of Oportunidades). ${ }^{18}$

Overall, although PROGRESA does not amount to an expansion as it is defined here given that it reached less than 35 percent of the relevant outsider population, it represents the groundwork on which subsequent expansion of income transfers would be based. In terms of transparency, efforts to reduce discretion, and nonparticipatory implementation, the contrast between PRONSASOL and PROGRESA is stark. Although both programs were launched by PRI administrations as their main social policy strategy for outsiders, their differences can be attributed to the political environments of electoral competition and democratization in each administration. Zedillo faced high levels of competition in a democratizing environment, as well as unprecedented competition for outsider voters when a credible challenger made more aggressive

${ }^{16}$ In the first years of the new fiscal law, however, some studies report biases in the federal allocation of resources (see Sour et al. 2004).

${ }_{17}$ Interviews, Székely; Rojas; Escobedo-Zoletto. For the use of resources by subnational units, see Benitez Iturbe (2009); Díaz-Cayeros, Estévez, and Magaloni (forthcoming).

${ }_{18}$ These concerns appear repeatedly in newspaper articles and interviews. Informants argued that external evaluations of PROGRESA helped highlight the efforts and achievements at creating a nondiscretionary program. On these allegations, see, for example, "Bloquean campesions un accesso a Tapachula," in El Universal, January I4, 2000. 
attempts to mobilize their support as the 2000 elections neared. By the end of the Zedillo administration, about 50 percent of the population in Mexico lived in municipalities governed by the opposition, in contrast to 2 percent when Salinas inaugurated PRONASOL in I988 (Lujambio 200I: 85 ). Under Zedillo, moreover, the incumbent party did not control the lower chamber of Congress, and electoral laws passed in 1996 limited the restrictions on the opposition and the advantages of the incumbent. By contrast, under Salinas, opposition parties competed on a much less favorable basis. The PRI's campaign spending far outstripped that of the opposition, and the party was able to use the state apparatus to ensure its continuity in power (see Greene 2007, Magaloni 2006). Moreover, it was able to manipulate electoral results and use repression against the opposition (interview, Cárdenas, PRD presidential candidate, I9882000, Magaloni 2006: 92), raising the cost of opposition party building (Greene 2007). ${ }^{19}$

\section{The 2000 Election}

The July 2000 presidential election was marked by intense electoral competition, and unlike the 1994 presidential election, it was not only free but fair. Until a few months before the election, PRI candidate Francisco Labastida was the frontrunner. In November 1999, when Labastida won the PRI's first primary elections, polls showed that he held a lead of 20 points with 53 percent of vote intention against 32 percent for Fox and Io percent for the PRD's candidate, Cuauhtémoc Cárdenas (Lujambio 200I: 88). In January 2000, this difference had shrunk to Io percentage points and polls showed a potential PRI victory or a technical tie since February 2000. ${ }^{20}$

In the last few months of the campaign Fox, who had launched a "catch-all" strategy appealing to voters around the issue of democracy and regime change, achieved decisive support to win the election. Fox

19 Magaloni notes that political confrontations emerged in several local elections in which the PRD competed against the PRI, resulting in close to 500 PRD activists murdered in these electoral confrontations under Salinas (Magaloni 2006:92).

${ }^{20}$ Lawson (2004) notes that in January 2000 Labastida led the polls for I 5 points. In the next months, polls showed Labastida's support eroding but even coming out first until the end of the campaign; see "Fox: Sólo aspiro a gobernar bien," in La Jornada, February 26,2000 . Others reported Labastida winning by a wide margin; see "El PRI bien posicionado para ganar las elecciones," La Jornada, March 22, 2000. Even a poll in June 2000 showed Labastida three points ahead, "Mantiene Labastida ventaja mínima," Reforma, June 22, 2000. 
invited all Mexicans to cast a useful vote "to get the PRI out of government," appealing to strategic opposition voters ${ }^{2 \mathrm{I}}$ who would support the candidate with the highest chance at defeating the incumbent (Greene 2007; Lujambio 200 I: 88-9). At the same time, Fox's campaign targeted outsider voters and especially sought to reach out to the countryside, seeking to mobilize the rural vote away from the PRI.

To mobilize support from low-income outsiders, Fox promised to maintain existing programs such as PROGRESA and to embark on further social investments. Social policy issues gained ground in the campaign agenda as competition tightened. Fearing an increase in vote intention for Fox in the context of a virtual tie between the candidates, Labastida promised to strengthen PROGRESA. ${ }^{22}$ As the election neared, Fox further pledged to double the funding for social programs and to expand health care services, stating, "my commitment is that every Mexican will have access to primary care and hospital services." ${ }^{23}$

Analysts of Mexican politics note that as voters became increasingly less attached to parties in the 1990s, the three main parties adopted catch-all strategies to gain votes outside their social bases (Greene 2007; Klesner 2005). As Klesner argues, even if opposition parties had distinct social bases that conditioned their ideological or programmatic orientation, they tried to reach voters broadly. In this context, Fox managed to gain support among outsiders.

Based on the data presented in Figures 6.3 and 6.4, we see that electoral competition for outsider voters was high in the July elections. Starting in 2000, under a democratic regime, outsiders were willing to support different parties across elections, rather than throwing their support primarily behind a single party as they had done in the past. Such levels of volatility among outsiders generated high incentives for reaching them via social policy to consolidate their support, as discussed later.

\subsection{ELECTORAL COMPETITION FOR OUTSIDERS AND SOCIAL POLICY EXPANSION}

Fox's victory in the 2000 presidential elections inaugurated the first PAN government and the first alternation of parties since the creation of the PRM, predecessor to the PRI, in I929. As president, Fox faced

\footnotetext{
${ }_{21}$ "Llama Fox a hacer útil el voto de la oposición," La Jornada, March 6, 2000.

${ }^{22}$ Quoted in "Se definen sobre UNAM, Fobaproa, el IVA y Chiapas," Reforma, May 26,2000 .

23 Ibid fn 2 I.
} 
the challenge of consolidating the broad electoral coalition that had brought him to power. This coalition comprised voters seeking regime change and alternation, historic PAN supporters, and low-income voters mobilized by the PAN through promises of change and social improvement. ${ }^{24}$ Regarding outsiders, a large majority of whom were poor, ${ }^{25}$ the PAN faced the dilemma of retaining their support through social policy appeals while simultaneously catering to its constituency in the economic elite, who preferred modest government intervention and market mechanisms in social policy.

When proposing and negotiating social policy for outsiders, PAN politicians therefore designed large-scale though restrictive social programs, reaching a relatively small pool of beneficiaries with modest benefit levels, especially compared to programs for insiders and provisions extended to outsiders in the inclusive models created in Argentina and Brazil. Specifically, the PAN proposed benefits that despite attaining unprecedented coverage were targeted to the poorest of outsiders.

As in other cases in which social policy expansion was propelled by electoral competition for outsider voters, the new policies and/or funding for these initiatives required negotiations with parties in Congress. The shape of the resulting policies depended on these parties' social policy preferences and their balance of power. In this regard, the PRI did not have a consistent social policy agenda for outsiders in the 2000 . The party had supported high levels of state intervention in programs for the formal sector until the r990s, when it embraced pro-market policies (see Brooks 2009; Madrid 2003; Murillo 2001). The Salinas administration pursued sweeping market-oriented reforms but kept social security systems virtually intact, while the Zedillo administration privatized the pension system run by the Mexican Institute of Social Security (IMSS) and tried, unsuccessfully, to liberalize health insurance. Social policy for outsiders promoted by the PRI in turn largely consisted of rural benefits: land distribution, which was executed unevenly until the I980s, and food programs and price subsidies, which benefited outsiders but often channeled more resources toward higher-income consumers. ${ }^{26}$ In the I990s, some PRI politicians preferred a more subsidiary role for the

\footnotetext{
${ }^{24}$ On the 2000 elections, see essays in Domínguez and Lawson (2004).

${ }^{25}$ Note that in 2000 , when outsiders represented 58 percent of the population, the poverty and indigence (extreme/food poverty) rates in the total population were 53.6 percent and 24. I percent, respectively (see CONEVAL 2006:7).

${ }^{26}$ See Chapter 3.
} 
state while others sought higher levels of state intervention in policies for low-income populations. Both of these sectors were relevant under Salinas, but the pro-market PRI politicians became more prominent during the Zedillo and the Fox administrations.

The PRD initially lacked a clear social policy agenda aside from opposing the pro-market reforms introduced by PRI politicians and advocating nondiscretionary provisions. This changed with the rise of AMLO, who sought to actively mobilize outsider support during his campaign. Programs for outsiders then became a key topic in the party's social policy agenda. Just like the PRI and the PAN, in a highly competitive environment, the PRD advocated nondiscretionary social policies with unmediated state implementation.

As advanced in this book's analytic argument, when political parties face electoral competition, they generally prefer to establish social policies with nonparticipatory implementation, both to avoid empowering organizations that may engage in demand-making, and out of concern that the involvement of social groups may generate allegations of patronage or benefit manipulation, which could discredit the incumbent administration. Despite the fact that some PRI legislators strongly preferred participatory social policies under Salinas, when facing a competitive environment, the PRI bloc in Congress did not actively promote participation in policy implementation in the social policies introduced in the 2000s.

During the period under examination, the president lacked a majority in both chambers. The distribution of power in the lower chamber was split between the PAN and PRI, and the PRI also had the largest bloc in the Senate and controlled several governorships. The PRD had a small share of seats in Congress and therefore little influence on policy design (see Table 6.2). To pass new social benefits or to obtain funding in the annual budget for social programs, which requires approval of the executive's budget proposal from the lower chamber only, the PAN needed backing from other parties. Fox especially needed PRI support until the last few months of his administration when the PRD became the second largest party in Congress.

Next, I characterize the social policy innovations of the Fox administration and discuss the reasons why restrictive designs were chosen. Because some of these innovations - especially those concerning pensions - were either more fully implemented or changed under Calderón, I refer further to his administration in the discussion of each policy area. 
TABLE 6.2 Composition of Congress, Mexico, 2000-2009

\begin{tabular}{|c|c|c|c|c|c|c|}
\hline & \multicolumn{2}{|c|}{$2000-2003$} & \multicolumn{2}{|c|}{$2003-2006$} & \multicolumn{2}{|c|}{$2006-2009$} \\
\hline & Chamber & Senate & Chamber & Senate & Chamber & Senate \\
\hline PRI & $2 I I$ & 60 & 224 & 57 & IO4 & 33 \\
\hline$\%$ & 42.2 & 46.9 & 44.8 & $44 \cdot 5$ & 20.8 & 25.8 \\
\hline PAN & 213 & 46 & I 5 I & 47 & 206 & 52 \\
\hline$\%$ & 46.6 & 35.9 & 30.2 & 36.7 & 41.2 & 40.6 \\
\hline PRD & $5 I$ & 16 & 97 & I 5 & I $58^{*}$ & 36 \\
\hline$\%$ & 10.2 & I 2.5 & 19.4 & II.7 & 31.6 & 28.I \\
\hline PVEM & II & 5 & I7 & 5 & 19 & 6 \\
\hline$\%$ & 2.2 & 3.9 & $3 \cdot 4$ & 3.9 & 3.8 & $4 \cdot 7$ \\
\hline Other & I 4 & I & II & 4 & I3 & $\mathrm{I}$ \\
\hline$\%$ & 2.8 & .8 & 2.2 & $3 . I$ & 2.6 & .8 \\
\hline Total & 500 & I 28 & 500 & I 28 & 500 & I 28 \\
\hline
\end{tabular}

* Includes sixteen from Convergencia and sixteen from Partido del Trabajo.

Note: 2000 alliance between the PAN and PVEM (Ecologist Green Party of Mexico); 2006 alliance between the PRI and PVEM.

Source: IFE-Sistema de Consulta de las Estadísticas Electorales 2000-I 2 (www.scieef.ife .org.mx).

\section{The Vicente Fox Administration (2000-2006)}

After taking office, Fox sought to solidify the support of outsiders through social policy. Fox transformed PROGRESA into a new income-transfer program, Oportunidades - which by 2003 reached more than twice the number of its original beneficiaries - and inaugurated health insurance for outsiders, a key innovation of his administration. Facing intense competition for outsiders surrounding the 2006 elections, when the PAN's continuity became threatened by the rise of AMLO, the Fox administration inaugurated means-tested pensions in an effort to offset the appeals of this credible challenger who promised large-scale pension expansion.

One major concern of the Fox administration was avoiding allegations of benefits manipulation, such as the ones that had characterized prior programs like PRONASOL. ${ }^{27}$ PAN legislators submitted a social development bill to Congress to create clear rules, transparency, and accountability mechanisms in social programs. ${ }^{28}$ Among other measures, the new law established an evaluation system and provided guidelines to

27 This concern about avoiding discretion in the selection of beneficiaries was particularly highlighted in interviews with Székely and Hernández.

${ }_{28}$ The PRI and PRD had also submitted bills, and Congress discussed all three projects. 
inform the population about existing benefits. ${ }^{29}$ This law was approved unanimously in the lower chamber. As advanced in this book's argument, both the incumbent and the opposition faced a highly competitive environment and therefore had incentives to support a law that established clear criteria and rules for social policy. As PRI legislator Sonia Rincón noted, "We need to keep on making progress on the institutionalization of public policies, even more now that alternation is a reality." ${ }^{\circ}$ In explaining both the decision to pass the law and the PRI's support for it, former president and legislator Felipe Calderón noted:

Social expenditure is so relevant that it has to be conceptualized as state policy not as the policy of a specific administration. With that in mind ... the legislators promoted the Social Development Law in 2004. The issue is that the opaque and discretionary administration of social programs can become your worst enemy because it creates divisions among and confronts political parties, levels of government, and beneficiaries themselves... Obviously, the PRI, an opposition party, then became interested in generating the transparency grounded in the law. (interview)

\section{Income Support}

The first innovation under Fox was the reform and expansion of the cash transfer program launched by Zedillo. Although Fox promised social policy expansion during the 2000 presidential campaign, there were doubts as to whether a PAN victory would keep PROGRESA in place, and there was profound mistrust among several PAN politicians toward the program, which they associated with the PRI (interviews, Hernández, Calderón). ${ }^{3}$ Before assuming office, the Fox transition team announced that the president-elect would maintain PROGRESA, noting, "on inauguration day we cannot tell 2.6 million families they will lose their benefits." ${ }^{2}$ Fox himself assured constituents he would maintain PROGRESA, ${ }^{33}$ and suggested that PROGRESA would be transformed into "PROGRESA Plus" and would grant every family in Mexico a

\footnotetext{
29 Some of those mechanisms already governed PROGRESA and Oportunidades, but were not present in other social programs (e.g., obligation to publicize the fact that benefits were accessible without political intermediaries and that receiving a benefit did not imply exchanging it for political support).

${ }^{30}$ Quoted in SEDESOL (2005: 8).

31 "Candado Electorero al Progresa," El Universal, May 9, 2000.

${ }^{32}$ Carlos Flores, social policy expert of the president-elect's team in "Fox preservará el Progresa, anuncia equipo de transición," La Jornada, July 2I, 2000.

33 See also "Evaluan retos de la política social," Reforma, July 2I, 2000.
} 
minimum income, guaranteed health treatments, pensions, and some savings for contingencies. ${ }^{34}$

In the next two years, and with an eye toward consolidating support, the Fox administration introduced important changes to PROGRESA. In 200I, Fox announced its extension to semi-urban areas, incorporating 800,000 beneficiaries, and increased the budget for social development, foreseeing a broader expansion of this program in following years. In 2002, Fox changed the name of PROGRESA to Oportunidades - partly to differentiate his approach from that of the PRI - and expanded the benefit to another million households. ${ }^{35}$ As an indicator of transparency in the distribution of benefits, Fox appointed Rogelio Gómez-Hermosillo, the head of Alianza Cívica, a nongovernmental organization involved in monitoring elections, as the director of Oportunidades.

By 2003 , the number of beneficiaries of Oportunidades had reached 4.3 million, almost twice as many as at the beginning of the Fox administration. A year later, the number of households covered was extended to 5 million, and school grants were provided, on average, to one child per family conditional on school attendance (see Figure 6.5). The expansion of Oportunidades to urban areas was not only championed by the PAN, but also requested by legislators from the opposition in congressional debates over annual budget allocations.

The program's design was restrictive. Despite its meaningful reach, Oportunidades covered only 36 percent of the outsider school-age children by 2010 , a scope that is here classified as low. ${ }^{36}$ Aside from targeting families in extreme poverty only, enrollment was further limited in a number of ways. As stated in several interviews with top officials of the program, at the end of the Fox administration Oportunidades had a wait list of families who qualified for the benefit. At the same time, several children in households reached by Oportunidades did not receive fellowships. These restrictions on the reach of the program to potentially eligible families and children operated through several mechanisms. First, the government established a quota of beneficiaries of 5 million households, which was increased to 5.8 million in 20I0. Even if people qualified for the benefit, they were not included until a spot opened up. Second, conditionality was strictly enforced and families who lost their

${ }^{34}$ In "Ofrece 'progresa plus' que asegure sustento," El Universal, November 22, 2000.

35 The expansion of Oportunidades was decided by the executive. The lower chamber in Congress voted to provide funding for the program.

${ }^{36}$ In the present study, a "low" scope of coverage is defined as between 35 percent and 50 percent of the population. 


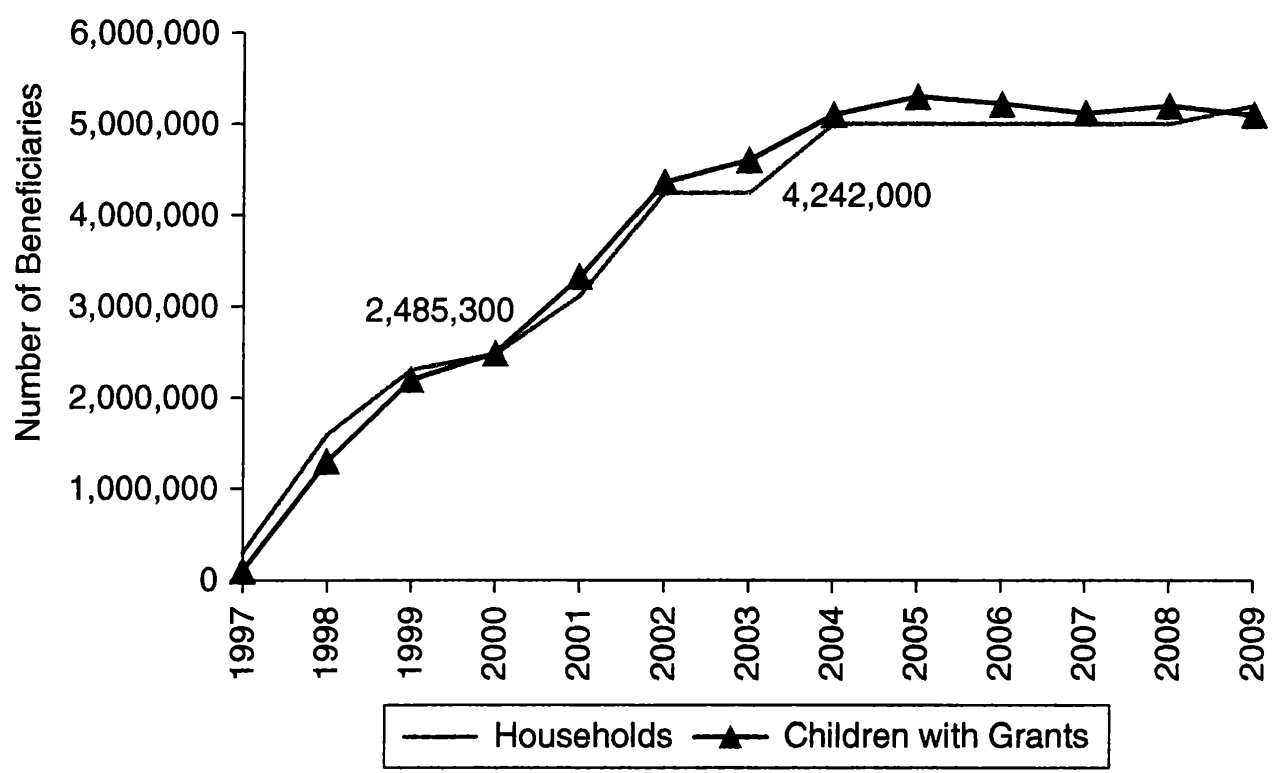

FIGURE 6.5 Beneficiaries of income transfers (Progresa and Oportunidades), I997-2009.

Source: SEDESOL.

benefits faced a wait period if they wished to reenter the program. Third, Oportunidades did not encourage children to go back to school if they had already dropped out. When asked about the low ratio of children with grants to protected families, especially compared to other cases under investigation, one top Oportunidades official suggested that mothers did not want all of their children to be enrolled in the scheme, and another noted that these figures reflected children who had dropped out of school and who therefore did not receive the benefit. Understanding household choices is beyond the scope of this project. The low number of recipients may be attributed to the difficulty of getting dropouts to return to school, but it also reflects the government's intention to reach many households while also keeping the program small. In Brazil, a country whose socioeconomic characteristics most resemble Mexico among the cases here analyzed, the ratio of children with grants to protected families has been consistently higher than one on average. Finally, it is worth noting that program officials at some point seriously considered the possibility of making the benefit conditional on academic performance. Yet that proposal was discarded, as it would potentially limit access even further (interview, Escobedo-Zoletto, director of Oportunidades).

Under the Fox and the Calderón administrations, the benefit level of Oportunidades was moderate. The program provided a grant to children in school, a food supplement to families in extreme poverty, and a 
TABLE 6.3 Benefit Level of Oportunidades, 2010

\begin{tabular}{lcccc}
\hline & $\begin{array}{c}\text { Total } \\
\text { Amount in } \\
\text { Pesos }\end{array}$ & $\begin{array}{c}\text { As Percent of } \\
\text { Extreme or } \\
\text { Food Poverty } \\
\text { Line }^{\mathrm{a}}\end{array}$ & $\begin{array}{c}\text { As Percent of } \\
\text { Poverty Line }^{\mathrm{b}}\end{array}$ & $\begin{array}{c}\text { As Percent } \\
\text { of Minimum } \\
\text { Wage }\end{array}$ \\
\hline $\begin{array}{c}\text { Benefit Household } \\
\text { with Two } \\
\begin{array}{c}\text { Children } \\
\text { Minimum Wage }\end{array}\end{array}$ & 906 & 35 & I7 & 53.10 \\
\hline
\end{tabular}

a Average of urban and rural linea pobreza alimentaria calculated by CONEVAL for 2010 times three (the equivalent of two adults and two children).

b Average of urban and rural linea pobreza carencias calculated by CONEVAL for 2010 (similar to poverty line defined by ECLAC) three times (for two adults and two children).

c Average benefit paid to households with one or two adults plus two children - one in primary and one in secondary school - provided they fulfill the conditionality (food support, food supplement, two average grants for primary and secondary school). Note that grants are provided ten months a year.

d Average of minimum wage (estimated with "Area A," 57.46 pesos per day and "Area C," 54.47 pesos per day times 30.5.

Sources: Estimates built with data from Oportunidades, CONEVAL (available at www .coneval.gob.mx), Servicios de Administración Tributaria (www.sat.gob.mx) and SEDESOL for July-December 20 Io.

small subsidy for electricity (which in Brazil and Argentina was provided separately). With the crisis in the late 2000 , a food supplement to compensate for food price hikes was added. The amount school grants paid varied according to grade level and, beginning in secondary education, varied according to gender to foment women's education. Although benefits could be high for older children, reaching over the minimum wage by the final year of high school, the average benefit paid to households (including fellowships, food support, and electricity subsidies) was lower. In 2010, the benefit paid to a hypothetical household with two children (including food support and two average grants for children in primary and secondary education) was equivalent to 36.3 percent of the cost of the food basket and I7.5 percent of the poverty line (see Table 6.3). Based on this last measure, the benefit level of Oportunidades is here considered moderate, as it stands between ro percent and 19 percent of the poverty line (see Appendix I). The coverage and benefit level of Oportunidades reflect a preference for limited government intervention, which the PAN and Zedillo administrations shared.

The PRD had different preferences with respect to income support. It contested the use of conditionality and advocated broader transfers, 
which were rejected by the PRI and PAN (interviews, Laurell, secretary of health and welfare, Mexico City; and Pérez-Bejarano, head of social welfare of the PRD's 2006 campaign). However, it could not influence the design of income transfers under Fox for a number of reasons. First, the PRD did not have enough power in Congress to affect policy making during the Fox administration. Second, the PRD prioritized other policy areas, such as pensions and health care, for which it had alternative policy proposals. PRD administrations in Mexico City in the 2000 s showcased the party's policy proposals and helped AMLO place social policy issues on the national agenda, but they did not launch any massive income-support program for children. In fact, the PRD did not have a specific policy proposal that could replace or significantly overhaul Oportunidades, as it did in the case of pensions and health care. According to the candidate for the Ministry of Social Development, in the event of a PRD government in 2006, Oportunidades would have been kept in place (interview, Pérez-Bejerano).

Just like PROGRESA, Oportunidades was administered directly by the national state and did not include social organizations in the program's implementation. In the absence of strong social movements that could demand involvement in participatory arrangements, political parties in a highly competitive party system preferred nonparticipatory implementation of large-scale income transfers. For PAN technocrats, the idea was to have "zero" community involvement (interview, high official of SEDESOL) to avoid what they perceived as unnecessary intermediation that could result in abuses.

\section{Health Care}

In 2003, the Fox administration formally launched its most ambitious social policy initiative, Seguro Popular (SP), which aimed to expand health insurance for outsiders. Due to its relevance and visibility, and the fact that it was an innovation introduced by Fox rather than an initiative inherited from the Zedillo administration, SP was undoubtedly the signature social program of the administration.

With the goal of gaining the support of outsiders, Fox promised to guarantee access to health services for those without formal social security coverage in his presidential campaign. After the elections, a transition team led by Julio Frenk - an internationally renowned public health expert and future secretary of health - began to work on a proposal for health care expansion that culminated in SP. At the time, outsiders could 
use health services through clinics and health posts run by the states, as Mexico's health care system had been decentralized in the I980s and I990s. Access to these services was limited due to inadequate infrastructure, especially outside of large cities, uneven provision of services, and lack of funding. User fees were collected at the point of delivery, raising barriers to the poor - almost half of the population of Mexico at the time. ${ }^{37}$

To promote SP and make its approval more likely, the executive followed a strategy similar to the one Zedillo used with PROGRESA. While working on the draft bill, the Secretariat of Health launched the pilot of what would ultimately become SP, covering 295,000 families by 2002 (Ortiz 2006: 43). The pilot program helped show that despite the dearth of funding and infrastructure in many localities, the implementation of SP was feasible, and provided PAN legislators with ammunition to defend the policy. According to Frenk, the pilot "included baseline surveys to see the health conditions of the families, their propensity to pay [for health insurance] ... a large number of studies... It was very important to have not just an abstract proposal but an annex that said: we have been doing this in several states and it is working." ${ }^{8}$ Once the pilot had been evaluated, Fox submitted the bill creating the System of Social Protection in Health Care - within which SP would operate - to Congress in November 2002.

SP was passed in April 2003 with support from the PAN and the PRI, which introduced few modifications to the original bill. The PRD had a different proposal for health care reform and opposed the initiative in the lower chamber. Yet given the party's small share of seats in both chambers, this had no impact on the policy's approval or design.

SP was designed as a restrictive health insurance for outsiders. According to the law, SP offers a package of basic health services contracted out from state, social security, or private providers. Affiliation is voluntary. While SP fully subsidizes the extremely poor, all other outsiders - most of whom were poor at the time - are required to pay an insurance premium according to their household income. Aside from premiums, $\mathrm{SP}$ is funded with resources provided by the national and state governments. ${ }^{39}$

37 Poverty data for 2002 from CONEVAL (2006: 7).

${ }^{38}$ Quoted in Ortiz (2006: 44), my translation.

39 Households were initially exempted from paying premiums if they were among the poorest 20 percent of the population. In 20I0, families with incomes up to the fourth-poorest decile were exempted. 
In order to gain support for the program and raise enough funding, implementation was agreed to be gradual. One of the biggest challenges facing SP was persuading households that would have to pay premiums to enroll. When the program was approved, it was estimated that about 55 million Mexicans lacked health insurance. SP established the goal of reaching more than 45 million people in $2010.4^{\circ}$ Coverage grew significantly between 2004 and 20IO, when SP affiliated 26.23 million people, about 4I percent of outsiders. ${ }^{4 \mathrm{I}}$ Out of this pool, the vast majority had fully subsidized insurance premiums. ${ }^{42}$

Regarding health treatments and/or interventions, SP guarantees basic rather than comprehensive coverage. The number of treatments included grew gradually from 90 in 2005 to 266 in 2008.43 High-complexity interventions, some of which were included within a fund for catastrophic expenses, were not fully covered by SP at the time. In this respect, SP resembles Chile's FONASA, which leaves some treatments uncovered or provides partial coverage. As in the case of pensions and income support, $\mathrm{SP}$ is implemented without the participation of organizations representing users or affiliates.

The structure of SP reflects the preferences of conservative politicians within the PAN. In expanding health services to consolidate support among outsiders, the PAN hoped to make the new policy compatible with the preferences of its core upper-income constituency - and the party's historic program - for a subsidiary, small role of the state and market expansion. This resulted in a program with rather modest reach and coverage in which affiliates, excluding the very poor, are required to pay an insurance premium to access services.

At the same time, the Fox administration pursued to a greater or lesser extent other goals with the expansion of health services. First, it sought to make more room for a private market of health care providers, and second, it aimed to reduce the power of the main social security institutions that provided health services to private and public formal workers, the IMSS and the Civil Servants' Social Security Institute (ISSSTE),

$4^{\circ}$ Estimated with data from INEGI's 2000 census. See Secretaría de Salud (2004: 3); "En marcha, El Seguro de Salud," La Jornada, May I 4, 2003.

${ }^{41}$ Estimate based on 2010 census data from INEGI. See discussion about discrepancies in coverage, which vary significantly depending on the source. The Secretariat of Health claims a much larger number of affiliated individuals than the data coming out of the census and other surveys, which all yield much smaller affiliation rates to SP. See CONEVAL (20I4), INEGI-ENESS (20I4), and Secretaría de Salud (20I3).

${ }^{42}$ See Secretaría de Salud (2004) and CONEVAL (2014).

43 Secretaría de Salud (2004: 3) and (2008: 62). 
respectively - as well as that of their powerful unions. These goals were also in line with the preferences of the core business constituency. In fact, the basic guidelines of SP coincide with the proposal for health reform put together by Funsalud, a foundation supported by the business community, which advocated the creation of public insurance for low-income people and a plural health care market that would foster the private provision of health services (Funsalud 200I).

Regarding the private provision of services, promoters of SP believed that because the IMSS and ISSTEE delivered services exclusively through their own facilities, they both discouraged the development of private provision, competition, and user choice, resulting in less effective services. In the words of Frenk, "social security of the twentieth century created a monopoly of providers without incentives to satisfy users' needs." 44 The expansion of health insurance for outsiders offered an opportunity to address such perceived distortion. Unlike the IMSS and ISSSTE, SP can contract out services from diverse private, public, and social security providers (e.g., hospitals, labs, clinics) and foster the growth of private contractors. 45

Another transformation more or less explicitly pursued through this reform was the erosion of the power of the social security institutions, which could potentially facilitate their overhaul in the future. There were several serious attempts at reforming the IMSS and ISSSTE since the I990s, which did not prosper largely owing to opposition from their labor unions (interview, Genaro Borrego, director of IMSS, 1992-2000). Essentially, these reforms aimed to reduce IMSS expenditures by contracting out services to private providers (interviews, Borrego and high IMSS official) and by scaling back labor contracts and pensions of IMSS employees (interviews, Vega-Galina, IMSS union secretary-general), which were particularly generous relative to the rest of the formal workforce.

Some labor union leaders saw the expansion of private providers fomented by the SP as a threat to the survival of the IMSS. While not opposing the protection of outsiders, they were wary of the potential effects of the new program. According to Francisco Hernández-Juárez, head of the National Union of Workers (UNT), private interests supporting SP were "working to dismantle the IMSS so that they capture that population [it serves] and benefit economically" (interview).

\footnotetext{
44 Frenk in Gómez Dantés (2005: 22).

45 Confidential interview.
} 
Promoters of SP initially considered the possibility of integrating it within the IMSS. ${ }^{46}$ Interviews with officials from the IMSS and from SEDESOL revealed that the government explicitly refused to expand services to outsiders through the IMSS because that would mean empowering IMSS and its workers' unions. ${ }^{47}$ In contrast to the government, union leaders believed the IMSS should manage the expansion of services to outsiders as it had some infrastructure and the capacity to administer a new large-scale program (interviews, Hernández Juárez, Vega-Galina). The IMSS already ran a program, IMSS-Coplamar, later called IMSSOportunidades, which provided very basic primary care in some rural areas and could be used as a platform to expand services (interview, director of IMSS-Oportunidades).

SP was approved in Congress with broad support from PAN legislators and from the PRI. Support from opposition senators was deemed critical for its passage and to enable its implementation, as senators largely responded to governors who would have to contribute to the program's funding and guarantee its operation (see Ortiz 2006). The PRD opposed SP. In the congressional debate, Senator Elías Moreno-Brizuela suggested the PRD had "discussed intensely the proposal" and had "contradictory views." He advocated voting against the policy because although SP would give more resources to the states and governors might see that as "a carrot," it would end up "impoverishing many states" because they would have to pay for part of the services extended by the program without adequate resources (Cámara de Senadores, April 24, 2003). The PRD also maintained that the new health care law opposed "universality" and "free access" by guaranteeing a reduced package of services and establishing premiums for low-income families. These two features, universal coverage and free access, were key aspects promoted by the party's alternative health policy proposal (interview Laurell, PRD's leading expert and secretary of health of Mexico City).

Close to half of the PRI's legislators supported the initiative in the lower chamber, which guaranteed its passage. ${ }^{8}$ In opposition, some PRI legislators argued that the measure would undercut IMSS-Oportunidades (legislators Victor Infante; Francisco López-González, Cámara de Diputados, April 29, 2003). The PRD, in turn, voted against the policy. PRD legislators rejected SP's separation from social security institutions,

${ }^{46}$ Noted by Frenk interviewed by Gómez Dantés (2005: I7).

47 Interviewees requested confidentiality.

${ }^{48}$ See http://gaceta.diputados.gob.mx/Gaceta/Votaciones/58/tabla3 or 2-48.php3 (accessed August 2009). 
arguing that universality had to be achieved by funding existing health care facilities (subsidizing the supply of services) to ensure free access for all. At the same time, and in line with PRD senators, others rejected the fact that SP provided access to "essential" rather than comprehensive services (statements by Adela Graniel-Campos, Cámara de Diputados, April 29, 2003). PRD experts furthermore believed that SP would segment access among low-income populations, providing only a limited set of treatments to people enrolled in the plan, and neglecting those not enrolled and/or seeking treatment for non-SP conditions. As we will see in Chapter 7, similar concerns emerged with the AUGE in Chile.

SP began implementation gradually. As skeptics had predicted, the lack of infrastructure proved decisive for the evolution of implementation in different localities (see Coneval 20I4). As Lakin noted, one critical aspect of SP that did not work as expected was the actual payment by the states of their required contributions. The national government in turn did little to modify this situation, hoping instead to strengthen the program and keep it in motion (see Lakin 2010). According to Calderón, who saw an important expansion in coverage during his tenure as president, the role of the states in SP's implementation was its weakness (interview, Calderón).

The other aspect of the program that did not take off was the collection of family premiums. In fact, initial reports showed non-indigent families being fully subsidized (Lakin 2010). Under Calderón, these requirements were eased and families within the four poorest income deciles were exempted from paying premiums, which helped expand the program's reach and avoid misclassification of beneficiaries or selective application of eligibility criteria.

In sum, SP was probably the most relevant expansion in Mexico and also the most challenging one given the infrastructure and funding required to accomplish its goals. This expansion was done in a top-down way in the context of electoral competition for outsiders. Its main programmatic features were discussed and designed by experts and negotiated in a Congress dominated by conservative politicians. The absence of social mobilization pressing for expansion and participating in the program's design helps account for the restrictive model adopted.

\section{Pensions}

Pension expansion was closely intertwined with the 2006 presidential election and the rise of AMLO, who posed a credible threat to the 
continuity of the PAN, and who promised to create a large-scale pension program. Well before the presidential campaign, in 2004 and 2005, opinion polls showed that if AMLO ran for president, he would win comfortably (see Lawson 2009: 7). During the 2006 race, the margin of difference narrowed, with AMLO having a ten-point lead (Lawson 2009: I).

The PRD and PAN competed intensely for the support of the lowincome electorate. The PRD-led coalition, with the slogan "For the Good of All, the Poor First," promised social policy expansion in its attempt to reach out to low-income voters nationally. AMLO had a strong record of social policy innovation. As Mexico City's head of government (2000-5), he launched a universal pension for people seventy and older - reaching 400,000 people in 2006 - access to free health services and medications, and pensions for people with disabilities and for orphans, which benefited 86,000 people (interview, Encinas, PRD mayor of Mexico City).

According to key PRD advisors and the opposition, these social policies amassed dramatic electoral support for the PRD in Mexico City, where the party won by a landslide in the midterm election of 2003.49 In particular, old-age pensions were widely recognized as a fundamental source of popularity for AMLO (interview, Boltvinik). A key social policy expert and PRD politician highlighted the "political brilliance" of AMLO when he decided to launch pensions, and suggested:

His political intuition enlightened him... There is an obvious thing: each senior is at the peak of a pyramid with a large base. If you assist all the seniors then everyone is happy because everybody has a parent, a grandparent. It is impressive the number of people who came to admire a political leader who launched a program reaching seniors. The increase in popularity attained with this program was impressive. Why wouldn't I vote for this candidate who did so much for my grandpa? (interview, PRD policy expert)

Under AMLO, social policy became a fundamental source of competition between the national and city governments. For example, PRD legislators representing Mexico City voted against SP in Congress, and AMLO initially refused to start its implementation in the district. ${ }^{\circ}{ }^{\circ}$ Although he claimed to support SP, ${ }^{\text {sI }}$ his was the last state to eventually agree with the

\footnotetext{
49 Interviews, Boltvinik, Encinas, confidential interview.

so "La Salud sin colores ni partidos, señala Frenk," La Jornada, January I4, 2005; "Sin acuerdo formal Fox pone en marcha el Seguro Popular en el DF," La Jornada, April 6, 2005. sr "Con austeridad viable en todo el país la pensión universal," La Jornada, March I4, 2005 .
} 
national government to start rolling it out, on the grounds that it had a different health care policy that provided free universal health care.

Tensions between Fox and AMLO surged surrounding a failed attempt by the PRI and the PAN to remove AMLO from office in Mexico City on the grounds that he had allegedly violated an injunction by opening a road on expropriated land. As Wuhs argued, this move "not only ultimately failed but also aggravated existing tensions along the parties and gave AMLO a significant bump in his approval ratings and overall political profile" (2008: I43).

Facing a real challenge to the PAN's continuity in power, President Fox initially discredited AMLO's programs. In particular, he dismissed noncontributory old-age pensions as "populist" and in criticizing the policy, stated:

Workers in firms, civil servants - all save to have a pension when they retire. I believe it is terribly unfair that just for being seniors, others are protected with precisely the money of those who work..$^{52}$

In response, AMLO noted that the pension program was "an act of justice" and suggested that social benefits could be paid for with a reduction of discretionary government expenditures and their reallocation toward social policy. ${ }^{53}$ In a public rally in Mexico City in which AMLO formally granted 2,700 new pension benefits, he argued that "an austerity plan of the national government" that reduced politicians' expenses and cut high salaries and privileges could spare enough to "guarantee the right to a food pension ... scholarships for people with disabilities, more housing, schools, and hospitals." 54

Soon after his critiques of AMLO's pension program, and aware of the difficulty that the PAN faced in the coming elections, Fox announced that his government was planning to launch a pension program for people sixty-five and older without social security coverage that would be funded with a "solidarity contribution from the national government" and with savings from beneficiaries. ${ }^{5}$ He further pledged that his government

52 Public statement quoted in "Fox vs. los programas sociales del DF," La Jornada, March I 8,2005 . This statement was noted in a number of interviews with PRD politicians.

53 "Con austeridad viable en todo el país la pensión universal," La Jornada, March I4, 2005 .

54 Ibid.

s5 "Pronto habrá un plan de jubilaciones para mayores de 65 años, anuncia Fox," La Jornada, April I7, 2005. 
would establish "three pillars of social justice" involving education, pensions, and the social security system, especially Seguro Popular..$^{56}$

In late 2005 , Fox's administration formally announced the extension of pensions for seniors in households receiving Oportunidades. In January 2006, the Fox administration began the distribution of close to 800,000 pensions to the poor through Oportunidades-Seniors to offset the momentum of the PRD's candidate. Oportunidades-Seniors provided a pension equivalent to $I 7$ percent of the minimum wage, well below the benefit AMLO had promised, which was equivalent to half of a minimum wage. The choice of Oportunidades as the structure through which the pensions would be distributed responded to the fact that it had operative capacity to implement a large program quickly. According to the director of Oportunidades, "clearly the intention was to create out of nowhere the capacity to put together a list of beneficiaries and extend the transfer" (interview, Gómez-Hermosillo, director of Oportunidades). At the same time, Fox requested a technocratic team to design a pension program out of which adults in households receiving Oportunidades could save for a future pension (interview, Székely).

Fox made further announcements that emphasized his commitment to consolidating social policy for outsiders in an effort to ensure their support for the PAN. In 2006, he inaugurated the Council of Social Protection (CPS), which sought to integrate different programs for outsiders (Oportunidades, Seguro Popular and Oportunidades-Seniors). The first meeting of the CPS was held on March 2006, three months before the national elections. On that occasion, Fox, who had previously rejected universal policies launched by the government of Mexico City, stated that: "To universalize social security is not only a mandate but an ethical and human imperative that cannot be procrastinated. Democracy is equity and equity means inclusion and opportunities to all Mexicans." 57

Facing a technical tie in the final months of the campaign, Calderón launched an increasingly aggressive attack against AMLO, portraying him in the media as a radical populist and a danger to Mexico. Coupled with campaign mistakes made by the PRD candidate, such as declining to participate in the presidential debate, the dirty campaign tactics helped

${ }^{56}$ See also "Fox planteará sistema de pensiones para los comerciantes informales," La Jornada, October I0, 2005.

57 "Fox insta a evitar el uso electoral de programas," La Jornada, March 24, 2006. 
pull Calderón ahead as the election neared, awarding him a razor-thin victory of less than half a point..$^{8}$

AMLO disputed the election results and claimed that the PAN had stolen the presidency. The PRD launched protests and an encampment in Mexico City, which lasted for months. Calderón took office in December 2006 in the context of political challenges to his legitimacy.

The pension program Oportunidades-Seniors Fox launched in the months prior to the elections was widely recognized by the PRD as well as by PAN politicians and policy makers as motivated by the centrality of pensions in the public agenda promoted by AMLO (interview, Encinas) and initiated to keep up with his candidacy (interview, Pérez-Bejerano). In the words of Gómez-Hermosillo, director of Oportunidades at the time:

Evidently the issue was brought into the public agenda by the subnational programs that started in Mexico City but in other states as well. It became an issue on the agenda, so it was necessary to find options and the government did not want to extend a universal pension. Fox's government did not believe that [a universal pension] was a good, progressive, solid measure... [One goal was to] give the message [that] the country would move towards a non-contributory pension. It had to be well targeted, it should not be a broad-reaching thing, universal in the false populist sense, but [it had to] really provide for the needs of those who do not have minimum income in old age. (interview)

Because this last-minute program expansion was regarded as polemic and, more importantly, given pressure from the PRD to create an institutionalized benefit in the context of high electoral competition and postelection conflict, the executive adopted a new pension program with clear eligibility rules in 2007 .

As soon as the new Congress assumed office in in September 2006, PRD legislators submitted a bill for a universal pension for seniors seventy and older and began to negotiate funding for this benefit within the 2007 annual budget law. The PRD was now the second-largest party in Mexico's Congress and the PAN hoped to win its support to govern and to get the annual budget approved. The PRD's proposal for pension expansion was discussed in the Commission for Vulnerable Groups, where legislators agreed to the PRD's initiative to create a more institutionalized benefit. At the same time, however, PAN legislators favored a more modest program and significantly lower funding than the one the PRD proposed. In explaining why conservative politicians agreed to extend pensions, Marta Pérez-Bejerano maintained that while they find it

${ }^{58}$ See an analysis of the campaign in Wuhs (2008: 143-6). 
hard to oppose to a popular policy, what they do is to "reduce the funding, lower the benefit level" (interview).

Instead of moving forward with the pension bill, funding for a pension program was negotiated among legislators of the PRD, PAN, and PRI, and was introduced within the 2007 annual budget. When Calderón assumed office in December 2006, Congress approved the 2007 budget, which included pension funding, with support from the PRD and the PRI (Cámara de Diputados, December 23, 2006).

Aside from seeking to court outsiders through pension expansion and to avoid blocking a popular proposal - PAN legislators supported the initiative as a fundamental concession to the PRD in exchange for its support to approve the annual budget (Velez, interview). For the PRD, the passage of the new program was an important achievement despite the post-electoral confrontation they maintained with the PAN. It signaled not only the PRD's influence on the national agenda, but also the accomplishment, at least in part, of its promise to create pensions for outsiders. As noted by PRD legislator Pablo Trejo, "A politics of dialogue, concertation, agreement ... is possible. We did it [negotiated] to achieve a social program that was our campaign commitment" (Cámara de Diputados, December 23, 2006). In the words of Perez-Bejerano, the new pension "was our victory ... there was opposition against it ... but after a long time we made them approve it" (interview). It is likely that PRD legislators expected voters to identify the pension program with their party, given AMLO's emphasis on pension expansion in his attempt to win the presidency.

The shape of the new benefit was restrictive. This resulted from negotiations among conservatives of the PAN and PRI with left-wing politicians of the PRD at a time in which conservatives had significant power. The PRD advocated a universal benefit for people seventy and older that would be implemented gradually. This pension would pay a benefit equivalent to 50 percent of a minimum wage (interview, Perez-Bejerano).59 The PAN, by contrast, supported a smaller benefit, reaching only the extreme poor aged seventy and older in low-income rural localities (interviews, Pérez-Bejerano and Navarro-Quintero, PRD legislator and proponent of the bill).

Despite their differences, legislators of all parties within the Social Development Commission voted unanimously for the program's guidelines, which were approved by Congress and adopted by the Calderón

\footnotetext{
s9 See the government program of the Coalition for the Good of All, the Poor First.
} 
administration in 2007. This benefit provided pensions of 500 pesos per month, equivalent to about one-third of the minimum wage, to the extreme poor in localities with fewer than 2,500 inhabitants. As in other policy areas in Mexico, benefits were implemented in a state-centric way without social participation. As expected in the analytical framework, in the absence of social movement involvement in policy making, benefits tend to be nonparticipatory. Political parties did not foster the involvement of social organizations in policy implementation in order to avoid empowering social groups, and to limit potential allegations of clientelism. In the following years, the scheme was extended to localities with up to 30,000 inhabitants. Despite these extensions, coverage remained low, as the program reached only about 48 percent of outsiders over sixty-five in 2010 (author's estimate, see Appendix I).

Note that prior to this policy, Fox had launched a small noncontributory pension, Program for the Assistance of Seniors (PAAM), for the extreme poor in rural areas in 2004, which involved the participation of rural organizations. PAAM was sparsely implemented and died out in the following years.

This small pension scheme was launched in the context of the National Agreement for the Countryside, in which the government negotiated agricultural policy with rural organizations (interview, Vélez). This renegotiation provided an incentive for rural organizations to coordinate joint action. ${ }^{60}$ Although the demands of rural organizations centered primarily on agriculture, the agreement signed in 2003 established a pension benefit for rural seniors in extreme poverty aged sixty and older.

In 2004, the number of beneficiaries was $24 \mathrm{I}, 000$ and later declined. ${ }^{6 r}$ Benefits were very small, representing about $\mathrm{I} 2$ percent of the minimum wage. A particularly interesting feature of this program was that rural organizations were involved in its administration, thereby benefits represented selective incentives more than nondiscretionary provisions. Although this scheme could have empowered the organizations involved, it was replaced with new pensions created in 2007 , which did not involve social participation. The fragmentation of interests regarding social policy among rural organizations and their focus on agriculture in their negotiations with the state probably made this small program much less important to them and limited its growth.

\footnotetext{
60 Acuerdo Nacional para el Campo (2003: I6); interview, Vélez.

6r Data from SEDESOL.
} 


\subsection{ASSESSING ALTERNATIVE EXPLANATIONS}

This section assesses the role of competing factors such as partisanship especially regarding the decision to expand social programs for outsiders - structural and economic change, and the diffusion of social protection models in social policy expansion and the model adopted.

As in the other cases under study, the partisan affiliation of the incumbent did not decisively shape decisions to expand - or not expand - social policies. The conservative PAN launched major social policy innovations. Therefore, although Mexico did not form part of the "left turn" in the region - that is, the arrival of left, or populist politicians governing on the left, to the national executive - it did experience dramatic social policy expansion.

Partisanship did matter, however, for the social policy model adopted. Negotiations about policy design involved the PRI and PAN - and later on the PRD - and resulted in restrictive benefits, which reflected the preferences of conservatives for small state intervention. The PRD advanced universal and more substantial policy initiatives compared to the PAN and the PRI. A greater role for the PRD in Congress starting in 2006 facilitated the approval of a pension program for outsiders that was restrictive, but slightly more generous than the scheme proposed by PAN legislators and the one launched by Fox in 2006. Thus, although partisanship does not account for why expansion happened, it does help explain why different benefit levels and/or coverage levels are chosen.

An assessment of the role of economic crises on policy change is particularly relevant in the case of Mexico, as this country suffered two important financial crises: the debt crisis of 1982 and the 1994 peso crisis. As discussed previously, the 1982 crisis did not trigger social policy expansion to deal with its immediate negative effects. The expansion of nondiscretionary policies began incipiently in 1997 after the financial and political crisis of $1994-5$ had badly eroded support for the PRI during the Zedillo administration. These policy changes were not launched immediately after the economic downfall of I994, even though they would have helped contain the negative social effects of the crisis and increased the legitimacy of the incumbent amid the financial collapse.

During the Fox administration, expansion occurred at different moments and in a context of economic stability. Despite the dramatic effects of the 2008 international crisis on the Mexican economy, health care and pension expansion continued their gradual implementation begun in 2004 and 2007, respectively. As discussed in the Argentine case, 

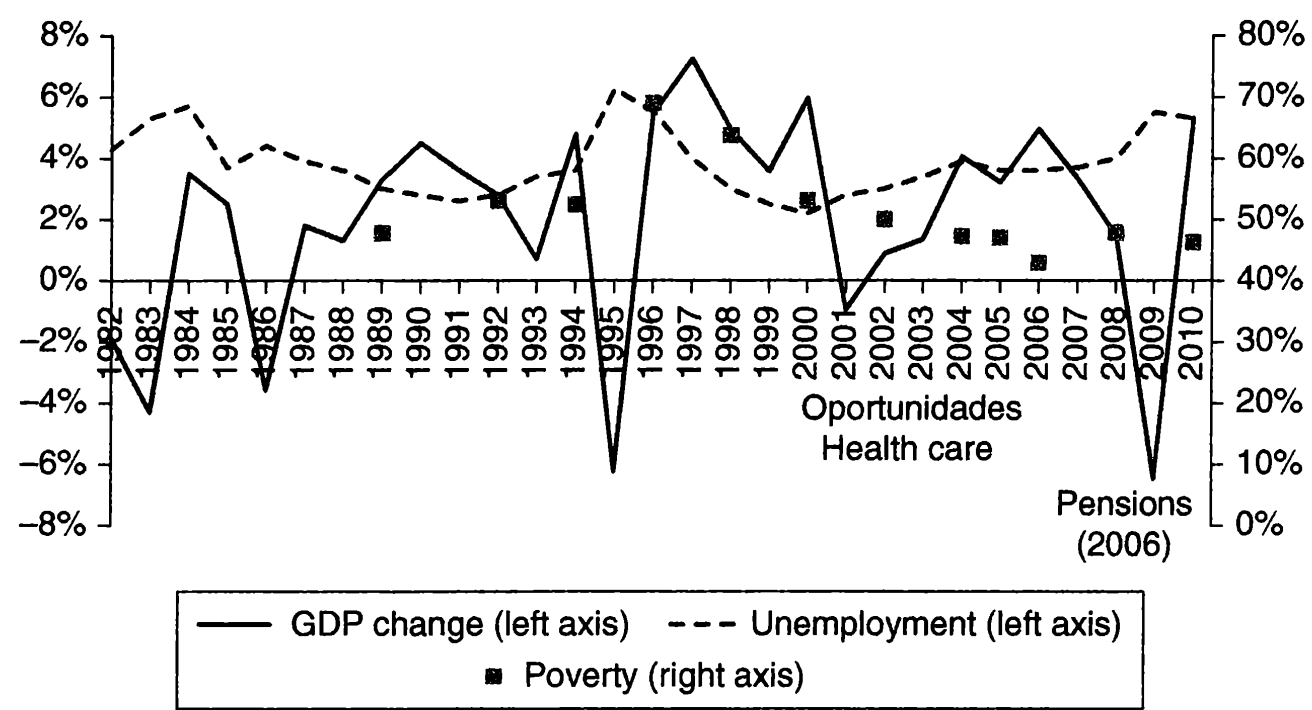

FIGURE 6.6 Economic growth, unemployment, poverty, and timing of expansion, Mexico, 1982-2010.

Sources: GDP and unemployment rate 1994-2009 from INEGI; I982-94 from Murillo (200I); poverty rate from CONEVAL.

crises may contribute in certain ways to social policy expansion when they intensify either the chances of parties competing for outsiders or the scale of mobilization from below. However, based on the analysis of the policy process and the chronology of policy expansion, crises by themselves do not have a direct systematic effect on policy expansion.

Economic prosperity and the lifting of tight fiscal constraints could also be factors that account for policy expansion. Looking at the evolution of GDP growth since 1982 (see Figure 6.6), we can see the absence of a clear pattern of social policy expansion linked to the evolution of GDP. Innovations began forcefully in 200I, 2003, and 2006. The gradual implementation of these policies made the whole period starting in $200 \mathrm{I}$ through 2010 one of a phased extension of benefits. This period in turn witnessed significant changes in GDP growth, which are not linked to decisions to expand. Indeed, $200 \mathrm{I}$ and 2009 experienced negative growth, and both saw either new social policy initiatives, such as the expansion of income transfers, or the continuation of pre-established gradual expansion of health care and pensions, respectively. From 2002 through 2008, moreover, the economy grew at levels similar to those of the early I990s, when nondiscretionary social policy expansion did not take shape.

Figure 6.6 also shows the evolution of poverty rates. We can see that Mexico has had high poverty rates throughout the whole period, particularly compared to Argentina and Chile. Available data show a sharp 
increase in poverty levels surrounding the 1994 crisis, when at least 70 percent of the population was poor. However, the Mexican state did not respond until a few years later with highly targeted direct transfers to low-income families, and it did so at a time when poverty was declining. In 1997, Zedillo launched PROGRESA, which reached Io percent of the households in the country in 1999, a small share given the level of deprivation. The increase of poverty in the r 990 os was thus not a major concern driving social policy innovations. Moreover, despite having a larger share of the population in poverty, the scope of transfers was relatively small, and reached only the rural poor until 2002.

Finally, the diffusion of policy models has not been a major factor shaping policy adoption and design. Even if specific policy tools, such as transfers for low-income families or a particular insurance system in the health care sector, have been popular in certain policy circles by the time of adoption, the decision to expand in the first place has been related to political needs. Responses to the question of how to appeal to outsiders led governments to look for policy tools and to reach out to experts in order to launch policies that would help them gain or consolidate outsiders' support in ways acceptable to the parties' core constituencies and compatible with their programmatic commitments.

\subsection{CONCLUSIONS}

Social policy expansion in Mexico occurred in the context of electoral competition for outsiders, which formed part of the broader process of democratization that ended the dominant party system based on the PRI. Electoral competition for outsiders drove incumbents first from the PRI, and then from the PAN, to respond to the emergence of credible challengers, that is, the emergence of parties that could defeat the incumbent by mobilizing electoral support among outsiders. Challengers seeking to win the vote of outsiders in turn promised social policy expansion to appeal to that constituency.

As suggested in the analytical framework, social policies created in the context of electoral competition are nondiscretionary. Incumbents fear that new policies will be considered clientelistic and will favor opposition parties competing intensely for outsiders. Opposition parties in turn strive to prevent incumbents from using social policy in discretionary ways, or to create temporary programs that would benefit the incumbent and the incumbent's party in the short term. Nondiscretionary policies are better in a context of intense competition and accusations of voter 
manipulation by the opposition. These dynamics were clear under the Zedillo administration, which dismantled PRONASOL and created the highly technocratic PROGRESA in response to accusations of clientelism and pressures from subnational authorities within highly competitive environments. PRONASOL was terminated due to its association with the Salinas administration, and was perceived as highly discretionary by subnational authorities and opposition parties pressing for decentralization. Under Fox, Congress passed the Social Development Law and institutionalized rules to avoid the manipulation of benefits. In this sense, the strategic goals of the incumbent and opposition parties led to the adoption of rule-based national social policies.

The resulting social policies in Mexico have been restrictive. In the country's new multiparty system, incumbents had to negotiate social policy expansion with the opposition in Congress. Because these innovations were popular measures, opposition parties had little incentive to block them, especially if they were competing for the vote of outsiders. Therefore opposition parties in Congress supported incumbents' proposals to expand social programs, and they also shaped the process of policy design. Given the large and powerful conservative presence in Congress, these social benefits have a smaller scope and lower benefit levels. In the absence of coalitions of social movements and labor unions pressing for large-scale expansion and participatory arrangements, political parties facing intense electoral competition opted for direct, state-centric implementation. 